\title{
Effect on Regional integration on Inter-regional Trade in Africa
}

\author{
Kossi AYENAGBO', Badoubatoba Mathieu DISSANI ${ }^{2}$ \\ ${ }^{1}$ Faculty of Economics and Management, University of Kara, Togo. \\ ${ }^{2}$ School of Economics, Capital University of Economics and Business, China, 100026.
}

\begin{abstract}
Regional integration offers participating countries advantages including the enlargement of the economic space, increased

efficiency and the development of interregional trade. In the

African regional communities, these assets are slow to emerge because of insufficient progress in the implementation of protocols, lack of economic diversification and various supplyside constraints. Moreover, Africa's ability to participate fully in world trade is currently hampered by weaknesses in private investment inflows, commodity dependence, non-existent or poorly developed infrastructure, and small regional markets
\end{abstract}

*Correspondence to Author: Kossi AYENAGBO Faculty of Economics and Management, University of Kara, Togo.

Keywords: Regional integration; Trade; Efficiency; Economic Development; Africa

How to cite this article:

Kossi AYENAGBO, Badoubatoba Mathieu DISSANI. Effect on Regional integration on Inter-regional Trade in Africa. Global journal of Economics and Business Administration, 2021; 6:35.

Classification JEL Codes: F11, F13, F15, O19, O24, O43, 055

\section{eScîPub}

eSciPub LLC, Houston, TX USA.

Website: http://escipub.com/ 


\section{Introduction}

Several facts justify the philosophy that African countries consider regional integration as a necessary and favorable condition for economic and social development. First, most of these countries are too small to individually constitute viable economic spaces. Second, these nations are unable to establish production units large enough to enjoy economies of scale and operate at competitive costs. Finally, they have no weight on the world economic stage and are largely marginalized in international negotiations. According to the Note on the Economy and Trade in Africa (Canada/Quebec,2019), Africa accounts for only $2 \%$ of gross domestic product (GDP) and $3 \%$ of world trade. Moreover, geographically or naturally, these countries on the African continent face disadvantages including landlockedness and insularity and they have increasingly pressing needs in terms of regional integration. All these concerns are part of the reasons that prompted African leaders to undertake various incentives for regional cooperation or integration in the aftermath of independence.

The progress made by regionalism in the world, particularly in Western Europe over the last ten decades, has contributed to giving new impetus to regional cooperation initiatives in Africa. Over the last six decades, regional integration in the African region has made significant progress, marked, on the one hand, at the subregional level by the restructuring of the Regional Economic Communities (RECs) and, on the other hand, at the continental level by the establishment of the African Economic Community (AEC) and the transformation of the Organization of African Unity (OAU) into the African Union (AU).

It is generally believed that strengthening regional cooperation relations can promote economic growth and, by extension, economic development through the positive effects this can have on intraregional trade (UNECA, 2004, Bakoup and Tarr, 2000; Gbetnkomet Avom 2005; Helmers and Pasteels, 2006). Despite the fact that the value of the overall trade of the countries of the region has more than tripled, the progress made over the last ten decades in regional integration does not seem to have been visible and perceptible on international trade and world trade in Africa. However, although commendable, this performance is low compared to the average of other developing countries, where progress has been twice as rapid.

In Africa, regional integration has led to the establishment of different levels of preferential trade areas by reducing tariff and non-tariff barriers and red tape among participating countries, and has enabled the implementation of community-based sectoral development programs. It has also led to the harmonization or coordination of national sectoral policies. Progress in the implementation of these policies should, in principle, promote interregional trade. In particular, improved cooperation in the transport sector will help reduce the physical and nonphysical barriers that impede the free movement of persons and goods. However, in the case of most African Regional Economic Communities, regional integration has not yet been able to produce the structural changes necessary for the vigorous and vibrant development of interregional trade. In particular, the optimization of the economic space through the programming of investments at the regional level and the relocation of production to localities with comparative advantages has been slow to materialize.

Indeed, trade liberalization is not a sufficient condition for the development of intra-regional trade. The real capacity of the countries 
concerned to meet the import demand of their community partners is an equally important factor. This capacity depends on the level of development, the degree of diversification of the economies and the product structure of the countries' international trade. In particular, the lack of complementarity between national products partly explains the low level of intracommunity trade in Regional Economic Communities such as the Common Market for Eastern and Southern Africa (COMESA), where the intraregional trade ratio is among the lowest in Africa, and the West African Economic and Monetary Union (WAEMU). On the other hand, the relatively high degree of diversification and complementarity of national production explains the more satisfactory state of intra-community trade in the Southern African Development Community (SADC).

Supply and demand factors determine how much a country can gain from participating in international trade. A country cannot sustainably participate in trade if it has the supply of tradable goods. The low level of international intraregional trade flows in Africa is partly due to supply-side constraints that undermine the productive sector (Bacchetta 2007, Oyejide, 2007a, 2007b). Regional integration can only truly produce the known effects of trade creation (Viner, 1950; Meade, 1955) if it takes place in a context where such constraints are effectively removed and where the supply of tradable goods has a reasonable degree of elasticity.

The objective of this research is to analyze the effect of regional integration on intra-regional trade in Africa. The research first assesses the theoretical link between integration and international trade, and then examines in concrete terms whether the integration process leads to increased intra-regional trade in Regional Economic Communities such as SADC, COMESA,
WAEMU, and ECOWAS. The study then analyze the relationship between regional integration and international trade in general and addresses the issue of intra-community trade in African Regional Economic Communities. The study first provides a brief review of the progress made by these Regional Economic Communities in regional integration. The study analysis the effect of this progress on intra-regional trade and draws a conclusion.

\section{Regional Integration and International Tra- de}

Since the work of Viner (1950), the effects of regional integration on economic performance and social welfare have been extensively explored (Oyejide et al., 1997; Baldwin et al.1998; Schiff and Winters, 1998, 2003; ADB, 2000; Burfisher et al., 2003; UNECA, 2004, 2006, 2008; CENUCED, 2007). Part of this work fits into the traditional Viner-Meade framework, which focuses the analysis on the possibilities of trade creation or detour.

\subsection{Trade liberalization and integration into world trade}

Regional integration can lead to general trade liberalization if it does not include measures to tighten trade barriers against third countries. It can, however, pose fundamental problems when Regional Economic Communities reach the stage of customs union. Consider the case of two East African countries, Kenya and Tanzania, both of which are members of the East African Community (EAC) but also belong separately to two other Regional Economic Communities, Kenya in COMESA and Tanzania in SADC. Each of the three Regional Economic Communities aims to reach at least the common market stage (UNECA, 2004). When the customs union stage is reached within COMESA, should Kenya apply the COMESA Common External Tariff (CET) to Tanzania or should it apply preferential 
treatment to Tanzania because of their mutual membership in the EAC. If Kenya is forced to choose the first option, i.e., the application of the COMESA CET, its membership in COMESA will contribute to a hardening of barriers against Tanzania as well as other countries with which it had preferential treatment. Many African countries, especially those belonging to more than one Regional Economic Community, are faced with this kind of dilemma.

The customs union would unambiguously contribute to the promotion of free trade if the CET applied by member countries to third countries was zero, which would not be possible since it would undermine the raison d'être of the regional integration organization $(\mathrm{RIO})$ or if the CET was lower than the lowest tariff initially applied by RIO countries. For all these reasons, the debate on the effect of the regional effect on global trade liberalization is far from over. Winters (1996) provides a review of the literature on the subject, see also Bhagwati (1991). Even if it satisfies the conditions defined in article 24 of the GATT, notably by renouncing increases in average tariffs, a free trade area is not necessarily a zone without barriers to trade. Within the European Union (EU), certain provisions of the competition laws allow member states to pose barriers to the flow of imports from other member nations. Similarly, within the North American Free Trade Agreement (NAFTA), antidumping laws are invoked by signatory countries to protect themselves against other member countries (Panagariya, 1998). Sometimes the RIOs themselves introduce protectionist provisions in favour of certain goods or sectors. This is particularly the case of the agricultural sector in the EU. To these provisions must be added rules of origin that further complicate the game and hinder the movement of goods between member countries.

\subsection{Trade creation and trade detour}

Research suggests that developing countries have much to gain from regional integration (ADB, 2000; Shiff, 2002; UNECA, 2004). According to Viner, regional integration can lead to the creation or detour of trade. Trade creation occurs when the integration process leads to an increase in the volume of trade between participating countries. It is due to the fact that trade liberalization within the Free Trade Area allows for lower costs, more efficient production and increased competitiveness in the area. Under these conditions, the phenomenon of trade creation leads to growth and improved welfare in the member countries of the Free Trade Area. Trade detour occurs when trade is diverted from a country that is not a member of the Free Trade Area, but more efficient, to a member country, but less efficient. The trade detour effect can occur in a customs union but not necessarily in a Free Trade Area. The tradecreating effect can look like a myth if a short-run static framework is considered. Indeed, it can be shown in a static analysis that if the member countries of the FTA are small, the trade detour effect is virtually inevitable (Bhagwati 1995; Panagariya 1996).

\subsubsection{Growth and welfare gains in the host country and the entire free trade area (FTA)}

Panagariya's $(1996,1998)$ thesis that trade detour is inevitable, while the welfare gain is not obvious. But the reality is much more complex. The analysis of the welfare gain must also take into account the surplus enjoyed by the producers of the good in the host country and its FTA partners. In addition, while integration allows participating countries to become more efficient and increase the scale of production, it can also lead to a welfare gain.

First, the gain in producer surplus in any FTA country will lead to income and demand growth 
and then likely to increased imports into that country. Part of this increase in imports may come from a host country, country $A$, resulting in a gain in producer surplus in country $A$, as in country B, an FTA country. This iterative process can continue and in the long run generate significant gains in growth and social welfare both in individual member countries and in the zone as a whole.

In addition, the protection that membership in the Free Trade Area offers member countries against third countries can lead to an increase in production and consumption throughout the area, including the host country. Although the phenomenon of trade detour remains a reality, the growth thus generated in the zone will lead to an increase in the volume of trade not only between the member countries of the zone but also between the zone and the rest of the world. Thus, integration benefits the countries that participate essentially through two channels: protection against third countries and the welfare gain due to the elimination of barriers to trade between these countries. But these benefits depend on the structure of production and consumption in the countries concerned. On the one hand, the creation of trade within the Free Trade Area will not take place if member countries are unable to meet the demand for imports from other member countries. On the other hand, for the gains in terms of producer surplus mentioned above to be realized, the supply of tradable goods must be elastic. In African FTAs, these conditions are often not met, limiting the effect of integration on intraregional trade and Growth.

Finally, the enlargement of the economic space made possible by regional integration can have positive effects on growth through the resulting efficiency gains. It makes it possible to optimize the use of productive resources, improve the economic environment and make investment programming more efficient, in particular by encouraging the inflow of foreign direct investment (FDI). In Western Europe, regional integration has contributed to growth in the least developed countries of the region such as Portugal, Spain, Greece and Ireland, but also to the stabilization of the economic environment in the more advanced countries such as Germany, France and the BENELUX countries. Statistics suggest that the phenomenon of conditional convergence predicted by the Solow (1956) and Swan (1956) model is taking place within the EU, given the relatively rapid growth in the less wealthy countries of the Union. Such a phenomenon was largely due to the mobility of factors of production within the zone, mainly from the more advanced to the less wealthy countries, and, in general, to the redesign of the production system on the scale of the Union as a whole rather than on the scale of individual countries. It is aware of these positive effects that African countries are making regional integration an essential component of their development policies.

\section{The problem of intra-regional trade in the regional economic communities}

Integration appears to be a necessity that can enable African countries to find regional cohesion in the face of the challenges and imperatives of globalization. Africa currently has a fairly large number of regional integration organizations (RIOs), about fifteen of which are Regional Economic Communities. However, the multiplication of RIOs is not the solution. On the contrary, the plethora of RIOs complicates and renders less effective the expected role of regional integration in development. In particular, the overlapping membership and objectives call into question the relevance of some of these organizations. Rationalization is needed to make 
regional integration organizations true "regional pillars" of the African economic community and to promote regional economic cooperation and trade (UNECA, 2004, 2006).

\subsection{Progress made by Africains countries in regional integration}

The majority of African Regional Economic Communities aim at the goal of full economic union. But progress toward such an objective is not being made rapidly in most cases. WAEMU and the Central African Economic and Monetary Community (CEMAC) are customs and monetary unions, while the Southern African Customs Union (SACU) and COMESA have reached the customs union stage. However, other African Regional Economic Communities are struggling to truly reach the Free Trade Area stage.

Over the past decade, African Regional Economic Communities have made unprecedented efforts to accelerate regional integration. They have implemented measures aimed, on the one hand, at curbing the factors that impede progress and, on the other hand, at introducing new avenues of cooperation while consolidating the gains of past efforts. Progress has been made and timetables set for reaching decisive stages of integration in Regional Economic Communities such as COMESA and SADC. In particular, SADC launched its customs union in 2012, following the example of the recently acceded COMESA.

But for the most part, progress is hampered by a lack of political will, which largely explains the low level of implementation of the protocols signed. All African Regional Economic Communities have particularly reached the FTA stage. However, the real problem remains the full implementation of the signed and ratified protocols. Often, even if customs duties are formally abolished, problems persist not only with the maintenance of non-tariff barriers but also with practices whereby countries impede the free movement of goods by using complicated interpretations of protocols on rules of origin. The lack of political will is partly explained by the fact that states measure the benefits and costs of scrupulous compliance with the agreements they have entered into. But often the analysis of these benefits and costs is done in a myopic way, losing sight of the long-term effects on individual countries and the community. In particular, states fear the loss of tax revenues that may result from complete liberalization of trade. In fact, customs duties still account for a large share of tax revenue in developing countries, as shown in Table 1 for some ECOWAS countries.

Table 1: Share of customs duties in tax revenue in some ECOWAS countries

\begin{tabular}{|c|c|c|c|c|c|c|c|c|c|c|}
\hline & 1996 & 1997 & 1998 & 1999 & 2000 & 2001 & 2002 & 2003 & 2004 & 2005 \\
\hline Benin & 45 & 46 & 43 & 46 & 16 & 17 & 17 & 14 & 21 & 20 \\
\hline Burkina-Faso & 44 & 45 & 38 & 38 & 27 & 34 & 29 & 18 & 19 & 22 \\
\hline Cote d'Ivoire & 37 & 37 & 37 & 36 & 36 & 35 & 35 & 20 & 25 & 23 \\
\hline Ghana & 23 & 24 & 26 & 25 & 17 & 16 & 22 & 10 & 29 & 31 \\
\hline Mali & 54 & 57 & 55 & 58 & 59 & 60 & 61 & 21 & 17 & 11 \\
\hline Niger & 38 & 42 & 42 & 40 & 16 & 17 & 17 & 14 & 21 & 20 \\
\hline Nigeria & 71 & 71 & 63 & 66 & 5 & 8 & 11 & 19 & 8 & 7 \\
\hline Senegal & 48 & 45 & 43 & 38 & 31 & 34 & 29 & 18 & 32 & 29 \\
\hline Togo & 27 & 26 & 26 & 24 & 26 & 37 & 48 & 46 & 18 & 54 \\
\hline
\end{tabular}

Source : ECOWAS, ECOWAS Economic and Social Indicators 1999, 2005, 2007. 
With the signing of the WTO agreements, the importance of customs duties in tax revenues is declining. However, nations tend to continue to protect this source of financial resources. Nevertheless, African states have made considerable progress toward the goal of regional integration. In all the Regional Economic Communities, unprecedented efforts have been made to abolish tariffs and reach the FTA milestone. As shown in Table 1, ECOWAS countries have significantly reduced tariffs over the last ten years, not only among themselves but also between the community and third countries. In addition, concrete steps are being taken to reduce non-tariff barriers (NTBs). In the ECOWAS zone in particular, the Observatory of Abnormal Practices (OPA) set up since the early 2000s has significantly reduced bottlenecks due to non-physical obstacles in some land transport corridors in the subregion. The number of Regional Economic Communities that have reached the customs union stage is growing; some Regional Economic Communities have set dates for reaching the common market stage. However, much remains to be done to achieve the desired objectives and enable regional integration to produce the desired effects on intraregional trade and development.

\subsection{Effects of Regional Integration on Intrare-}

\section{gional Trade in Africa}

These effects can be measured in relation to the volume and intensity of intra-regional trade, on the one hand, and in relation to social welfare in the countries concerned, on the other. They are still limited in the case of regional economic communities.

\subsubsection{Effects on the volume and intensity of intra-regional trade}

Intra-African trade has increased significantly in volume and value over the last three decades. But its product structure has seen little change in most cases. Between 1998 and 2007, the value of intra-community trade increased by $88 \%$, $186 \%$, and $192 \%$ respectively in SADC, ECOWAS, and COMESA. This is an extensive growth that is essentially due to the growth of economic activity and not to a structural change resulting from integration. Indeed, during this period, the total value of international trade increased by $136 \%, 287 \%$ and $316 \%$ respectively in these three regional economic communities. Thus, in all these Regional Economic Communities, the performance of intra-community trade was weaker than that of total trade despite the progress made in the implementation of the protocols on regional integration. Con- sequently, the share of intra-community trade in total trade has followed a downward trend (Table 2).

Table 2: Intra-Community Trade Ratio in Selected African Regional Economics Communitties

\begin{tabular}{|c|c|c|c|c|c|c|c|c|c|c|}
\hline & 1998 & 1999 & 2000 & 2001 & 2002 & 2003 & 2004 & 2005 & 2006 & 2007 \\
\hline ECOWAS & 13 & 11 & 10 & 12 & 13 & 11 & 10 & 13 & 14 & 9 \\
\hline COMESA & 7 & 6 & 7 & 8 & 5 & 5 & 4 & 4 & 4 & 4 \\
\hline SADC & 17 & 17 & 15 & 16 & 17 & 18 & 15 & 16 & 12 & 13 \\
\hline
\end{tabular}

Sources: COMESA, COMESA Merchandise Trade Statistics 2008 Bulletin N0.7; SADC, SADC Trade Statistics 2008; ECOWAS, ECOWAS External Trade Statistics 2007

The decline in the intensity of intra-community trade suggests that the regional integration process has produced few favorable effects on this branch of trade. Such a situation does not seem to support the argument of regionalists who believe that regional trade and development 
can be promoted through regional integration. Rather, it seems to support the thesis of multilateralisms that integration is not a sufficient or necessary condition for export growth.

The thesis of regionalists is supported by work based on general equilibrium models such as Bakoup and Tarr (2000) and gravity models such as Gbetnkom and Avom (2005), Achy (2006) and Helmers and Pasteel (2006) which suggest that intra-regional trade has great potential in Africa. This work gives prominence to factors such as geography in the regional structure of trade. The models used in this work can be quite effective in estimating parameters relating to trade potential in the context of regions with developed economies. However, they are not necessarily equipped to perform as well in the context of developing regions where supply elasticity is low due to the degree of industrializ- ation and diversification, which is also low.

The product structure dictates the structure by country or region of international trade. Indeed, apart from re-export activities, a country can only export the goods or services it produces. The more diversified the production structure, the stronger the country's capacity to export. The lack of diversification or complementarity of national production structures is detrimental to the development of intra-regional trade in the African Regional Economic Communities. In Regional Economic Communities such as COMESA and ECOWAS, few primary agricultural and mineral products dominate exports while imports are diversified and intensive in manufactured products. As long as the gap between the structure of imports and exports remains significant, intraregional trade cannot develop harmoniously.

Table 3: Share of manufactured products in the trade of SACU countries

\begin{tabular}{|c|c|c|c|c|}
\hline South Africa & Botswana & Lesotho & Namibia & Swaziland \\
\hline 56,5 & 90,6 & 87,4 & 40,1 & 76,4 \\
\hline
\end{tabular}

Source: UNCTAD, UNECA Handbook of Statistics 2005

The situation is different in SADC where SACU countries (which is included in SADC) dominate regional production and trade. The export structure of SACU countries is more diversified and contains more manufactured products than those of other regional economic communities, as suggested in Table 3. It is therefore the export structure that explains the intensity of intracommunity trade in SACU and SADC because, from the point of view of the implementation of the protocols on regional integration, SADC is not ahead of COMESA, ECOWAS or WAEMU. In fact, the intra-community trade ratio is only 1.1 $\%$ and 11.8 respectively in CEMAC and WAEMU, compared to $15 \%$ in SADC (83\% in SADC excluding South Africa), which has not even reached the stage of the Full Free Trade Area.

\subsubsection{Welfare Effect: Trade Creation or Diversion}

According to the Viner-Meade framework, integration affects social welfare through the potential effects of trade creation or trade detour. In the African Regional Economic Communities, these effects should not be significant given the low intensity of intra-community trade. A simplified way to assess trade creation or trade detour effects is to determine the correlation between intra- and extra-community imports. In particular, if trade detour occurs, the correlation will be negative between the two variables. In such a case, the growth of intra-Community imports causes a reduction in extra-Community 
imports. Above, this correlation is evaluated through a regression equation in which extra-EU exports are the dependent variable. The regression is carried out with panel data from the member countries of the Regional Economic Communities between 1998 and 2007 in the light of the available data. Table 4 presents the results of the regression exercise.

According to the results summarized in Table 4, WAEMU is the only Regional Economic Community where intra-community imports have negative effects on extra-community imports, as theory suggests when trade detour occurs.
However, the estimated coefficients are not statistically significant, which suggests that in this Regional Economic Community, the trade detour effect does not dominate. However, it cannot be concluded a priori that trade is created insofar as intra-regional trade is growing less rapidly than international trade as a whole. Thus, it cannot be concluded on the basis of the foregoing that the regional integration process at its current stage has a significant effect on social welfare in the African Regional Economic Communities.

Table 4: Regression of extra-community imports on intra-community imports

\begin{tabular}{|c|c|c|c|c|c|c|}
\hline \multicolumn{7}{|c|}{ (a) COMESA } \\
\hline \multirow[b]{2}{*}{ Intraimport } & \multirow{2}{*}{$\begin{array}{c}\text { Coef. } \\
0.3709488\end{array}$} & \multirow{2}{*}{$\begin{array}{r}\text { Std. Err. } \\
1.625433\end{array}$} & \multirow{2}{*}{$\begin{array}{c}T \\
0.23\end{array}$} & \multirow{2}{*}{$\begin{array}{c}\text { Pit } \\
0.820\end{array}$} & \multicolumn{2}{|c|}{ [95\% Intervalle conf] } \\
\hline & & & & & -2.849638 & 3.591535 \\
\hline Constante & 2941.046 & 307.0405 & 9.58 & 0.000 & 2332.684 & 3549. 407 \\
\hline \multicolumn{2}{|l|}{$R^{2}=0.0786$} & Nombre d'ob & $\mathrm{ns}=132$ & & & \\
\hline
\end{tabular}

(b) ECOWAS

\begin{tabular}{|ccccccc|}
\hline & Coef. & Std. Err. & $\mathrm{T}$ & $\mathrm{P}$ t & \multicolumn{2}{c|}{$[95 \%$ Intervalle conf $]$} \\
Intraimport & 0.7754871 & 1.066785 & 0.73 & 0.470 & 1.359915 & 2.910889 \\
Constante & 2431.008 & 430.7534 & 5.64 & 0.000 & 1568.761 & 3293.255 \\
\hline \multicolumn{3}{r}{} & $\mathrm{R}^{2}=0.0630$ & \multicolumn{3}{c}{ Nombre d'observations $=74$} \\
\hline
\end{tabular}

(c) WAEMU

\begin{tabular}{|ccccccc|}
\hline & Coef. & Std. Err. & $T$ & P tt & \multicolumn{2}{c|}{$[95 \%$ Intervalle conf $]$} \\
Intraimport & -0.0290599 & 0.7749179 & -0.04 & 0.970 & -1.571803 & 1.513683 \\
Constante & 591.2744 & 51.44503 & 11.49 & 0.000 & 488.8552 & 693.6936 \\
\hline \multicolumn{5}{c}{$R^{2}=0.0630$} & \multicolumn{2}{c}{ Nombre d'observations $=87$} \\
\hline
\end{tabular}

(d) SADC

\begin{tabular}{|lllllll|}
\hline & Coef. & Std. Err. & $T$ & \multicolumn{2}{c|}{ P t } & \multicolumn{2}{c|}{ [95\% Intervalle conf] } \\
Intraimport & 4.85679 & 0.7063266 & 6.88 & 0.000 & 3.458781 & 6.254817 \\
Constante & 493.6399 & 744.8909 & -0.66 & 0.509 & -1967.988 & 980.7079 \\
& & & & & & \\
\hline
\end{tabular}


Imports are an endogenous variable. To get around endogeneity problems, lagged values of the explanatory variable have been used instead of current values.

\subsection{Factors inhibiting intra-regional trade in} Africa

Factors inhibiting the development of intracommunity trade in Africa include, in addition to insufficient progress in the implementation of protocols on regional integration, lack of diversification and complementarity of national production, supply constraints, and inappropriate economic policies.

\subsubsection{Lack of Diversification and Comple- mentarity of Production}

Progress in regional integration initiatives is an important but not sufficient condition for the development of intraregional trade. Even if the protocols on the formation of the Free Trade Area are implemented, the countries concerned can only export if they produce or if there is a real demand for the goods they produce. Demand for the goods produced by a country increases with the degree of diversification of the production structure of that country. On the other hand, diversification is a function of the level of development and the degree of industrialization. In all the African Regional Economic Communities, countries with a surplus intra-community trade balance (Nigeria and Cote d'Ivoire in ECOWAS, Kenya in COMESA, and South Africa in SADC) are those with the best industrial bases in their respective regions. In SADC in particular, $83 \%$ of the import demand of member countries without South Africa is met by community production mainly because of South Africa's export diversification and industrial development. The good trade performance of Asian countries over the last decades is mainly the consequence of the progress made by these countries in the field of industrialization. The sustained increase in the share of manufactured products in exports has been one of the causes of the rise in the share of these countries in world exports. In particular, the share of manufactured products in Chinese exports rose from $42.2 \%$ in 1985 to 71.4 in 1990 and then to $90.6 \%$ in 2004. During this period, the value of Chinese exports increased by more than $2000 \%$ compared to $300 \%$ for world exports. This increased China's share in world exports from $0.9 \%$ to $6.4 \%$ (Oyejide, 2007b).

This position of China contrasts with that of African countries where exports are dominated by few primary products. The lack of diversification is one of the factors underlying the weak performance of African countries. Compared to the analysis of (UNECACE, 2006) on the inevitability of the short-run trade detour effect, the rate of trade growth has been lower in Africa than in other regions of the world over the last three decades. In particular, the long-term rate (1980-2007) has been twice as high in other developing countries as in Africa.

As a result, Africa's share in world trade is not only low but has declined sharply since the early 1980s, as shown in table 5.

Table 5: Africa's share of world trade

\begin{tabular}{|c|c|c|c|c|c|c|c|c|c|c|c|c|}
\hline & 1980 & 1990 & 1995 & 1999 & 2000 & 2001 & 2002 & 2003 & 2004 & 2005 & 2006 & 2007 \\
\hline Exports & 5.9 & 3.2 & 2.2 & 2.0 & 2.3 & 2.2 & 2.3 & 2.4 & 2.5 & 2.9 & 3.2 & 3.1 \\
\hline Imports & 4.6 & 2.9 & 2.5 & 2.2 & 2.0 & 2.1 & 2.1 & 2.2 & 2.2 & 2.3 & 2.3 & 2.2 \\
\hline Total & 5.3 & 3.0 & 2.3 & 2.1 & 2.1 & 2.2 & 2.2 & 2.3 & 2.3 & 2.6 & 2.7 & 2.7 \\
\hline
\end{tabular}

Source: CENUCED, UNCTAD Handbook of Statistics 2006: UNDESA, World Economic Outlook 2008 


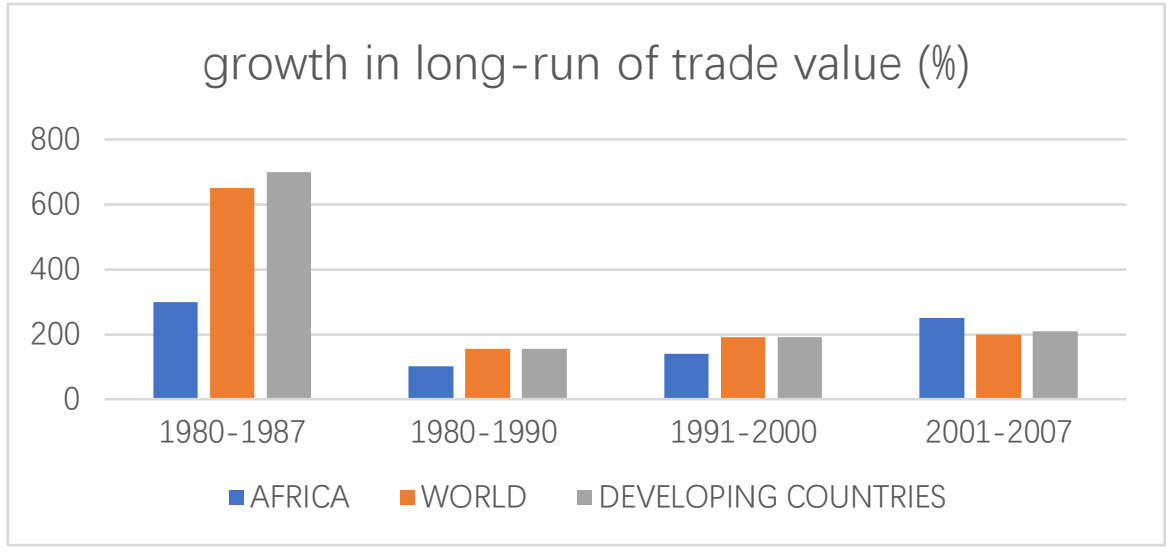

Source: UNCTAD Handbook of Statistics, 2006; UNDESA, World Economic Outlook, 2008.

The share of manufactured products in the exports of countries in the region, which rose from $22 \%$ in 1990 to $26 \%$ in 2004 , is still low. Africa is the continent where the manufacturing intensity of exports is the lowest in the world. The potential offered by the agro-food industry and other natural resource processing industries as well as the labor-intensive manufacturing sector is not sufficiently exploited. Oyejide (2007b) suggests that goods in Standard International Trade Classification (SITC) group 8 consisting of various manufactured products offer the best opportunities for export diversification in Africa. This group, which experienced an annual growth rate of close to $9 \%$ in the $1990 \mathrm{~s}$, deserves more attention.

In addition to industrial development, the existence and intensification of intra-community trade require that national production be complementary, according to the basic principles of comparative advantage. Complementarity increases the need and capacity to exchange. In SADC, the development of the South African manufacturing industry represents a favorable condition for the development of intra-regional trade. In the other Regional Economic Communities, countries have few products to trade since their production has similar structures.

Experience in other regions of the world sugges- ts that trade liberalization alone is not enough to stimulate intra-community trade. In Western Europe and in East and Southeast Asia, the intensification of intra-regional trade has been fostered by three factors: economic growth, the deepening of the regional integration process and the emergence of strong states around which the regional integration process has been articulated (ADB 2006; UNCTAD, 2007). Growth has been facilitated, as suggested by the neoclassical model, by several interdependent factors including the accumulation of production factors, particularly capital formation. The deepening of the integration process requires the achievement of stages beyond that of FTAs. In Western Europe, it has been facilitated by the establishment of the common market. The development of other aspects of trade, including intra-regional FDI and inter- and intra-industry trade, has been the result of this phenomenon. These three favorable factors are not always present in the case of the African Regional Economic Communities. First, economic growth has been unsatisfactory in most countries of the region over the last five decades (Ndulu et al.2008). In addition, the integration process is still fragile and is only in its early stages in the majority of the Regional Economic Communities. Finally, in each Regional Economic Community 
there is at least one state with some economic capacity. But often these States are not strong enough to play the role of catalyst in the integration process. In SADC, South Africa can play this role. However, it has not yet been able to do so because of several unfavorable factors, including the early stage of the integration process, the lack of progress in the implementation of protocols and institutional rigidities.

\subsubsection{Factors inhibiting African trade in general}

The factors that inhibit intra-community trade are also those that inhibit international trade in general. These factors can be classified into two broad categories, namely low supply capacity and inappropriate industrial and trade policies.

African countries face a structural problem of supply constraints that reduces their ability to compete in the global market. Such a situation hinders the development of intraregional trade since it affects export competitiveness. High transaction costs are among the most important supply-side constraints in Africa (Lyakurwa, 2007; Eifert et al., 2005). Other factors, including high labor costs, relative price imbalances, and national exchange rates, contribute to the weakening of Africa's international trade position. Conducting business costs $20 \%$ to $40 \%$ more in Africa than in other regions of the world (World Bank, 2006). These high costs have led to the loss of competitiveness experienced by African countries over the last three decades.

In general, the weak position of African countries is due to structural problems stemming in part from inappropriate economic policies (Yeats et al. Ndulu et al. 2008). African countries have undertaken structural reforms over the last three decades to redress the situation. Macroeconomic performance has improved somewhat, to be sure. However, much remains to be done to enhance the competitiveness of countries in the region.

African countries recognized early on the importance of the role of industrialization in economic development: Most of them have adopted various industrial development policies aimed mainly at increasing the share of manufactured products in production, and have implemented industrial policies. Unfortunately, these policies did not produce the expected results because they were essentially based on import substitution strategies requiring complex tariff structures and quantitative restrictions (Oyejide, 2007a; Bacchetta, 2007). It is well known that such policies cause distortions between the relative prices of tradable and nontradable goods, which are detrimental to the efficient allocation of resources and lead to inferior production structures and impede growth and trade (Dornbush, 1974). Here again, the situation of African countries contrasts with that of East Asian countries that have adopted export promotion policies instead.

The industrial and trade policies of African countries that are heavily oriented towards import substitution strategies have contributed to Africa's marginalization in world trade. Sachs and Werner (1995, 1997) and Collier (1995) argue that these policies have seriously harmed Africa by causing it to become increasingly introverted at a time when other regions have become more extroverted. It is generally accepted that extroversion improves the competitive environment, competitiveness, and efficiency of resource allocation. Trade openness makes it possible to highlight and exploit countries' comparative advantages (Dollar, 1992; Oyejide and Ogunkola (2004).

With the progress made in the implementation of the protocols on regional integration, African countries should favor economic policies that promote trade and growth. Industrialization 
remains a major challenge in the current context where low incomes and insufficient savings hamper capital formation, and where the low return on capital, low labor productivity and unstable socio-political environment that characterizes many of these countries do not favor the entry of foreign direct investment.

\section{Conclusions and Recommendations}

\subsection{Conclusions}

Over the last three decades, African countries have made considerable progress in developing the implementation of various protocols on regional integration in the hope of promoting development through, among other things, the intensification of inter-regional trade. The latter has seen significant development in the small SACU countries and significant progress in the landlocked countries of all the Regional Economic Communities. However, its overall performance remains insufficient.

Indeed, progress in the implementation of regional integration initiatives is an important but not sufficient condition for the development of intra-regional trade. Even if the protocols on the formation of FTAs are implemented, the countries concerned can only export if they produce or if there is a real demand for the goods they produce. Essentially, the factors inhibiting the development of intra-community trade in Africa include, in addition to insufficient progress in the implementation of the protocols on regional integration, lack of diversification and complementarity of national production, supply constraints and inappropriate economic policies. Intra-community trade has acquired a higher level of intensity in SADC than in the other African Regional Economic Communities because of the development of the South African economy and, in general, the diversification of the export structure in this subregion. In the other subregions, national production is less diversified and less complementary, which limits the countries' capacity to trade. In reality, however, intra-regional African trade faces the same problems as those that hamper the development of African trade in general. These are essentially supply-side constraints that limit the ability of countries to respond favorably to the incentives offered by regional integration protocols. In addition, the trade and industrial policies implemented by most African countries after independence have not led to the desired diversification. On the contrary, they have contributed to the marginalization of the African continent.

In order for intra-regional trade to benefit from the progress made in the implementation of regional integration programs, the countries concerned must recognize the importance of the supply side. Production must be organized on a regional rather than national basis, on the basis of economic policies that promote efficiency and competitiveness. Industrialization remains a formidable challenge in the current context where low incomes and insufficient savings hamper capital formation. Industrial policies must be guided by optimization criteria defined at the regional level and highlighting countries' comparative advantages.

Given the unavailability of data, we have used the available data to arrive at the results of this study.

\subsection{Recommendations: Promotion of regio- nal integration as a factor in increasing intra- community trade}

Improved regional cooperation can contribute to the reduction of barriers such as transport costs, rules of origin, standards and other regulatory obstacles, and poor customs administration.

Andrea Goldstein in her publication: "The New Regionalism in Sub-Saharan Africa: Does the Tree Hide a Forest? Andrea Goldstein, in her 
publication "The New Regionalism in SubSaharan Africa: Does the Tree Hide a Forest?" argues that in order to improve access to global markets, increase capital flows and stimulate economic exchanges between African countries, forms of cooperation that involve some harmonization of economic policies or the implementation of joint infrastructure projects are needed.

Regional integration is important:

\section{- To transform African economies}

Regional integration is a necessary condition for the transformation and growth of African economies, but also for Africa's integration into the global economy. This would allow for more efficient production in line with the theory of comparative advantage, and larger markets will allow for better exploitation of economies of scale. The resulting changes would improve the quality and quantity of production factors and gradually modernize them through technological progress. Moreover, factor mobility, coupled with coordination and harmonization of monetary and fiscal policies, would boost economic growth and improve welfare in the countries concerned.

- To free up industrial and commercial activity The other need relates to the fact that regional integration in Africa relates to its long-term effects on the organization of industrial and commercial activities.

- First, increased competition among firms will lead the least efficient among them to improve their operating mechanisms while others, unable to adapt to the new environment, will have to disappear. This emerging competitive environment will promote growth and profit and benefit the consumer.

- Second, many manufacturing activities will be able to establish themselves on a larger scale, thereby broadening the industrial base so necessary for the transformation of African economi- es.

-Third, greater opportunities for investment (domestic and foreign) will allow for the mobilization and deployment of more funds to tap the continent's vast natural resources, develop the enormous pool of human resources, and take advantage of savings opportunities.

- To enter the global economy Regionalization can also work in favor of multilateralism in the following ways:

- Going beyond the narrow issues of trade and global welfare and taking measures to promote foreign investment, human capital and technical development, infrastructure development, rational use of natural resources and environmental conservation.

- By acting as an instrument that limits the temptation to turn inward and paves the way for reforms in the trade sector.

- By creating larger political-economic groupings that are able to make their voices heard more forcefully in international forums.

- By creating export-friendly interest groups that are able to oppose national protectionism.

- Encouraging competition in domestic markets, lower prices and improved quality to ensure better competitiveness of products in international markets.

Africa should gradually become a full member of the global economy and thus avoid further marginalization.

\section{Conflict of interest}

There is not conflict if interest

\section{Acknowledgments}

We acknowledge those who contribute to the improvement of the manuscript

\section{References}

[1] Achy, Lahsen (2006), "Assessing Regional Integration Potential in North Africa". Paper prepared for the Twenty First Meeting of the Intergovernmental Committee of Experts, Rabat, $\mathrm{M}$ 
oroco, April.

[2] Bacchetta, Marc (2007, "Realsing Export Constraints : The Role of Governments." Paper presented at the AERC Collaborative Research Workshop on Export Supply Response Constraints in Africa, Dar es Salaam, Tanzania April.

[3] BAD (2000), African Development Report 2000 :Regional Integration Oxford: Oxford University Press.

[4] Bakoup, Ferdinand and David Tarr (2000), The Economic Effets of Integration in the Central African Economic and Monetary Community : Some General Equilibrium Estimates for Cameroon". African Development Review 12(2) : 161-90

[5] Baldwin, Richard, David Cole, Andre Sapir and Anthony Venables (1998), Regional Integration. Cambridge: Cambridge University University Press.

[6] BAsD (2006). Asian Development Outlook 2006. Hong Kong: Banque Asiatique de Développement.

[7] Bhagwati, Jagdish (1991), The World Trading System at Risk. Princeton, New Jersey : Princeton University Press.

[8] Bhagwati, Jagdish (1995), " US Trade Policy: the infatuation with Free Trade Areas," in Jagdish Bhagwati and Anne O. Krueger, eds., The Dangerous Drift to Preferential Trade Agreements, Washington, DC : American Entreprise Institute for Public Policy Research,

[9] Burfisher, Mary, Sherman Robinson Karen Thierfelder (2003), " Regionalism Old and New, Theory and Pratice, " paper Presented at the International Conference on Agricultural Policy Reform and the WTO : Where are We Headed ? Capri, Italy, June 23-26

[10] Canada, Québec (2019) .Note sur l'Economie et le Commerce en Afrique, Ministère de l'Economie et de l'Innovation
[11] CEDEAO (1990), Traité Revissé de la CEDEAO, Abuja : Secrétariat de la CEDEAO

[12] CEDEAO (2007), rapport annuel 2007, Abuja : Commission de la CEDEAO

[13] CENUCED (2005), Manuel de statistiques de la CENUCED 2005, Geneva : United Nations

[14] CENUCED (2007, Trade and Development Report 2007: Regional Cooperation for development, Geneva : United Nations

[15] CENUCED( 2008), World Investment report, Geneva : United Nations

[16] Collier, Paul (1995). "The Marginalization of Africa," International Labour Review 143(4) : 541-57

[17] Collier, Paul (2007). " Africa's Economic Growth : Opportunities and Contraints." African Development Review 19(1) : 6-25

[18] COMESA (1993), Treaty Etablishing the Common Market for Eastern and Southern Africa, Lusaka : COMESA Secratariat

[19] COMESA (2007), COMESA Strategic Plan 2007-2010, Lusaka : COMESA Secratariat

[20] COMESA (2007), annuel report 2007 , Lusaka : COMESA Secratariat

[21] COMESA (2008), COMESA Merchandise Trade Statistics 2008 Bulletin N0.7, Lusaka.

[22] Dollar, David (1992), " open economies Do grow more rapidly," journal of economic development and culutre change 40 (3) : 523-44

[23] Dornbusch, Rudiger (1974), " Tariffs and Nontraded Goods," Journal,of International Economics 4 (May) : 177-85

[24] Eifter, Benn, Alan Gelb and Vijaya Ramachandra (2005), " Business Environment and Comparative Advantage in africa : Evidence from the investment climate data;" Working Paper No.56, center for global development, washington, D.C.

[25] Gbetnkom, Daniel and Désiré Awom (2005), "Integration par le marchee: le cas de I'UEMOA." Region et Développement No.22 
[26] Geld, Alan, Vijaya Ramachandra and Gringer Turner (2007), "Stimulating Growth and Investment in Africa: From Macro to Micro Reforms." African Development Review 19(1) : 26-51

[27] Helmers, Christian and Jean Michel Pasteels (2006), " Assessing Bilateral Trade Potential at the Commodity Level: An Operational Approach." ITC Working Paper, November

[28] Lyakurwa, William (2007), "The Bussiness of Exporting: Transmission Cost Foreign Suppliers in Sub-Saharan Africa." Paper Presented at the AERC Collaborative Research Workshop on Export Supply Response Constraints in Africa, Dar es Salaam, Tanzania April

[29] Meade, James E.(1995), The Theory of Customs unions . Amsterdam : North Holland

[30] Ndudu, Benno J, Stephen A. O'Connell, Robert H. Bates, Paul Collier and Chukwuma C. Soludo (2008), The Political Economy of Economic Growth in Africa. Cambridge: Cambridge University Press

[31] OECD (2009), African Economic outlook 2009, Paris :OECD

[32] Oyejide , T. Ademola (1993), "The Oil Boom, Macroeconomic Policies and Nigeraian Agriculture: Analysis of a Dutch Disease Phenomenon. In Bautista and Valdesn, eds. The Bias against Agriculture. San Francisco : ICEG, ICS Press

[33] Oyejide , T. Ademola (2004)," African Export Supply Sesponse Capacity: an exploratory analaysis." Mimeo AERC Nairobi

[34] Oyejide , T. Ademola (2007a), african trade, investment and exchange rate regimes and incentives for exporting." Papper presented at the AERC Collaborative Research Workshop on Export Supply Response Constraints in Africa, Dar es Salaam, Tanzania April

[35] Oyejide , T. Ademola (2007b) " Relaxing Export
Supply Constraints and Promoting Export Expansion and Diversification in Africa : The role of Special Export Development Strategies." African Development Review 19(1) : 96-122

[36] Oyejide, T. Ademola and E.O. Ogunkola (2004)

"Trade Investment and Growth in Africa: Patterns, Trends and Puzzles." The Nigerian Journal of Economic and Social Studies 46(2) : 125-45

[37] Growth in Africa : Patterns, Trends and Puzzles, Ibrahim Elbadawi and Paul Collier (1997), Regional Integration and Trade Liberalization in Sub -Saharan Africa: Framework Issues and Methodological Perspectives Volume 1. New York : Saint Martin's Press

[38] Panagariya, Arvind (1996), " The Free trade Area of the Americas : Good for Latin America?" World Economy 19(5) : 485-515

[39] Panagariya, Arvind (2000, "Preferential trade Liberalization: The Traditional theory and New Development," Journal of Economic Littérature 38 (2) : 287-331

[40] Traditional Theory and New Development (2002), " EU Preferential Trade Arrangements and Devepping Countries, World Development, 25 (10) : 1415-1432

[41] Sachs, Jeffrey D. and Andrew Warner (1995), Economic Reform and the Process of Global Integration., Brookings Papers on Economic Activity $1: 1-95$

[42] Sachs, Jeffrey D. and Andrew Warner (1997), Sources of Slow Growth in African Economies." Journal of Economies 6 (3) : 335-76

[43] SADC( 2008), SADC Free Trade Area Handbook, Gaborone

[44] SADC( 2008), Official SADC Trade, Industry and Investment Review Gaborone: SADC Secretariat

[45] Schiff, Maurice and L. Alan Winters (1998), Regional Integration as Diplomacy," The World Bank Economic Review 12(2) : 251-70 
[46] Diplomacy (2003), Regional Integration and Development. New York: oxford University Press

[47] Solow, Robert (1956), " A Contribution to the Theory of Economic Growth," Quarterly Journal of Economics $70: 65-94$

[48] Swan, Trevor W.(1956), Economic Growth and Capital Accumulation," Economic Record 32 : 334-361

[49] Thirlwall, A.P. (2000), Trade Agreement, Trade Liberalization and Economic Growth: A Selective Study, African Development Review 12 (2) : 129-60

[50] Thirlwall, A.P. (2006), " The structure of Production, the Balance of Payment and Growth in Developing Countries: An Essay in Memory of Mohammed Nureldin Hussain 1954-2005., African Development Review 18(1) : 98-122

[51] UNECA (2004), Assessing Regional Integration in Africa, Addis Ababa : UNECA
[52] UNECA (2007), Economic Report on Africa 2007: Accelerating Africa's Development through Diversification. Addis Ababa : UNECA

[53] UNECA (2008), Assessing Regional Integration in Africa III, Africa Ababa : UNECA

[54] UNECA (2009), Economic Report on Africa, Addis Ababa : UNECA

[55] Viner, Jacob (1950), The Customs Union Issue. New York: Carnegie Endowment for International Peace, Chapter 4

[56] World Bank (2000), Can Africa Claim the 21st Century ? Washington : World Bank

[57] World Bank (2006), Doing Business in 2007." From www.doingbusiness.org.

[58] Yeats, Alexander, Azita Amjadi, Ulrich Eincke and Francis Ng (1997), " Did Domestic Policies Marginalize Africa in World Trade ? World Bank Directions in Development Series. The World Bank, Washington, D.C. 